Abstracta Iranicacta Iranica

Revue bibliographique pour le domaine irano-aryen

Volume 23 | 2002

Comptes rendus des publications de $\mathbf{2 0 0 0}$

\title{
Har-nāme. A. Dehbāšī éd., Tehrān, Ketāb-e panjere, 1379/2000, 220 p. + 4 ill. [Le livre de l'âne]
}

\section{Christophe Balaÿ}

\section{(2) OpenEdition}

Journals

Édition électronique

URL : http://journals.openedition.org/abstractairanica/35873

DOI : 10.4000/abstractairanica.35873

ISSN : 1961-960X

Éditeur :

CNRS (UMR 7528 Mondes iraniens et indiens), Éditions de l'IFRI

Édition imprimée

Date de publication : 15 mai 2002

ISSN : 0240-8910

Référence électronique

Christophe Balaÿ, « Har-nāme. A. Dehbāšĩ éd., Tehrān, Ketāb-e panjere, 1379/2000, 220 p. + 4 ill. [Le livre de l'âne] ", Abstracta Iranica [En ligne], Volume 23 | 2002, document 311, mis en ligne le 08 février 2010, consulté le 25 septembre 2020. URL : http://journals.openedition.org/abstractairanica/35873 ; DOI : https://doi.org/10.4000/abstractairanica.35873

Ce document a été généré automatiquement le 25 septembre 2020.

Tous droits réservés 


\section{Huar-nāme. A. Dehbāšī éd., Tehrān, Ketāb-e panjere, 1379/2000, 220 p. + 4 ill. [Le livre de l'âne]}

\section{Christophe Balaÿ}

1 Avec une note de Mojtabā Mīnovī et une introduction de Fereydūn Ādamiyat, l'éditeur nous livre ici un texte rare, publié en lithographie peu avant la mort de son auteur, ministre de Nașereddīn Šāh. Mais le contenu de cette "belle infidèle " était suffisamment critique et satirique à l'égard d'Amīnossolțān pour que le roi en ordonnât la saisie. L'ouvrage est en fait une traduction des « Mémoires d'un âne » de la Comtesse de Ségur, revue, corrigée et augmentée par E'temādossalțane avec la participation note Ādamiyat - d'Aminnoddowle, dont les idées sur le droit national marquent le texte. Le livre de l'âne est donc à inscrire parmi les textes qui contribuèrent à l'avènement de la démocratie en Iran. La note de Mīnovī permet d'établir la bibliographie du texte. Grâce au travail minutieux d'A. Dehbāšī, ce texte important et savoureux est à nouveau disponible. Il est précédé d'une notice biographique au sujet d'E'temādossalțane par Sd. Farīd Qāsemī (Mašāhīr-e mațbū'āt-e İrān, $1^{\mathrm{er}}$ volume). Le texte d'Ādamiyat est extrait de « Idéologie du mouvement constitutionnel iranien », Payām éd., 1355/1976.

\section{INDEX}

Thèmes : 11.1.2. Littérature persane moderne 
AUTEURS

CHRISTOPHE BALAŸ

IFRI - Téhéran 